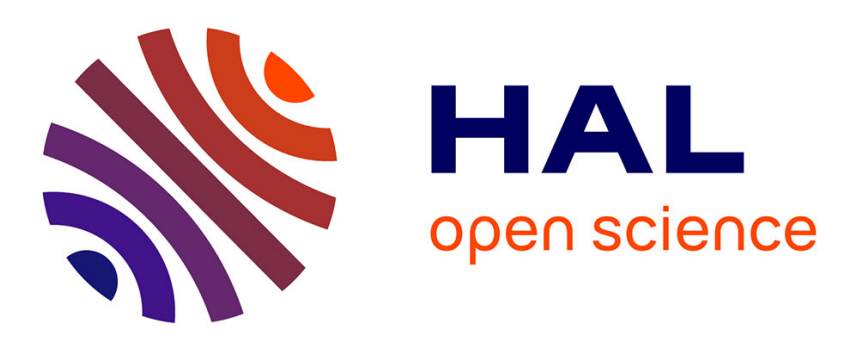

\title{
Association of a Glu92Lys substitution in MC1R with extended brown in Japanese quail (Coturnix japonica)
}

\author{
N.J. Nadeau, Francis F. Minvielle, N.I. Mundy
}

\section{To cite this version:}

N.J. Nadeau, Francis F. Minvielle, N.I. Mundy. Association of a Glu92Lys substitution in MC1R with extended brown in Japanese quail (Coturnix japonica). Animal Genetics, 2006, 37, pp.287-289. hal-02656381

\section{HAL Id: hal-02656381 \\ https://hal.inrae.fr/hal-02656381}

Submitted on 29 May 2020

HAL is a multi-disciplinary open access archive for the deposit and dissemination of scientific research documents, whether they are published or not. The documents may come from teaching and research institutions in France or abroad, or from public or private research centers.
L'archive ouverte pluridisciplinaire HAL, est destinée au dépôt et à la diffusion de documents scientifiques de niveau recherche, publiés ou non, émanant des établissements d'enseignement et de recherche français ou étrangers, des laboratoires publics ou privés. 


\title{
Association of a Glu92Lys substitution in MC1R with extended brown in Japanese quail (Coturnix japonica)
}

\author{
N. J. Nadeau*, F. Minvielle ${ }^{\dagger}$ and N. I. Mundy* \\ *Department of Zoology, University of Cambridge, Downing Street, Cambridge CB2 3EJ, UK. 'UMR Génétique et Diversité Animales, INRA \\ bât 211, 78352 Jouy-en-Josas Cedex, France
}

\section{Summary}

\begin{abstract}
We investigated melanocortin 1 receptor $(M C 1 R)$ as a candidate locus for the Extended brown phenotype in quail, in which there is a general darkening throughout the plumage. An initial screen of variation in MC1R in Extended brown and in wild-type quails revealed two polymorphic non-synonymous sites. One of these sites, a G-to-A substitution leading to a Glu92Lys mutation, was perfectly associated with plumage phenotype; all Extended brown birds were homozygous for Lys92. Co-segregation of the Glu92Lys mutation with the Extended brown phenotype was confirmed in 24 progeny of an $E / e^{+} \times E / e^{+}$cross. Glu92Lys is likely to be the causative mutation for the increased melanism in Extended brown, given that the same mutation is associated with melanic plumage in many breeds of domestic chicken, as well as in a wild passerine bird (the bananaquit, Coereba flaveola) and laboratory mice. Interestingly, the increase in melanization with the Glu92Lys mutation is less marked in quails than in most other birds and mammals. Phylogenetic results indicate that the Glu92Lys mutation has independently occurred in quail and chicken lineages.
\end{abstract}

Keywords extended brown, MC1R, melanism, quail.
The MC1R (melanocortin 1 receptor) locus encodes a seventransmembrane G-protein coupled receptor that plays a key role in the regulation of eumelanin/phaeomelanin production by feather bud and hair follicle melanocytes (reviewed in Jackson 1997). Variation in MC1R is associated with feather colour or hair colour variation in a wide variety of domesticated and wild species (e.g. Robbins et al. 1993; Klungland et al. 1995; Nachman et al. 2003). In birds, a potential role of MC1R in plumage colour was first documented in chickens (Takeuchi et al. 1996a,b). Subsequent studies have confirmed this initial finding, and shown that several amino acid variants in MC1R probably contribute to the plumage colour phenotype (Kerje et al. 2003; Ling et al. 2003). Variation in $M C 1 R$ is also associated with melanic phenotypes in three wild bird species: bananaquit, lesser snow goose and arctic skua (Theron et al. 2001; Mundy et al. 2004).

The Extended brown (E) mutation in Japanese quail is an autosomal incomplete dominant mutation associated with feather darkening in both sexes (Cheng \& Kimura 1990),

Address for correspondence

N. I. Mundy, Department of Zoology, University of Cambridge, Downing Street, Cambridge CB2 3EJ, UK.

E-mail: nim21@cam.ac.uk

Accepted for publication 13 February 2006 and these features are consistent with an effect at MC1R. We therefore investigated whether $M C 1 R$ variation was associated with Extended brown. Initial screens were carried out on two wild-type Japanese quail and three Extended brown quail: two from a French flock and one with a darker phenotype from a Japanese flock. A 859-bp segment of the 945-bp single coding exon of MC1R was amplified using primers MSHR72 (ATGCCAGTGAGGGCAACCA) and MSHR78 (CAGGAGCACAGCACCACCTC). Polymerase chain reaction (PCR) products were directly sequenced on both strands using the PCR primers and two internal primers: MSHR73 (GGCGTAGAAGATGGTGATGTAGC) and MSHR74 (GTGGACCGCTACATCACCAT). Sequences were edited in Seqman (DNASTAR, GATC Biotech, Konstanz, Germany) and manually aligned with other MC1R sequences.

Of two synonymous and two non-synonymous substitutions present in Japanese quails (Table 1), a single nonsynonymous substitution (Glu92Lys) showed a perfect association with plumage phenotype. The three Extended brown individuals from French and Japanese sources were homozygous for Lys92 whereas the two wild-type Japanese birds were homozygous for Glu92. To assess this association further, we investigated co-segregation of the Glu92Lys mutation and plumage colour in 24 progeny from two $E / e^{+} \times E / e^{+}$crosses. Eight male progeny of each of the three 
Table $1 M C 1 R$ variation in Japanese quail and domestic fowl.

\begin{tabular}{|c|c|c|c|c|c|c|c|c|c|c|c|c|c|c|c|c|c|}
\hline Species & Phenotype & Allele & 24 & 33 & 37 & 58 & 71 & 92 & 110 & 126 & 133 & 143 & 177 & 213 & 215 & 244 & Accession no. \\
\hline \multirow[t]{2}{*}{ Japanese quail } & Wild-type & $e^{+}$ & $\mathrm{T}$ & C & $\mathrm{D}$ & $V / I$ & $M$ & $\mathbf{E}^{1}$ & 1 & v & $\mathrm{L}$ & $\mathrm{T}$ & $\mathrm{F}$ & C & $\mathrm{H}$ & L & DQ395091 \\
\hline & Extended brown & $E$ & - & - & - & $V / I$ & - & $\mathbf{K}^{1}$ & - & - & - & - & - & - & - & - & DQ395089/90 \\
\hline \multirow[t]{6}{*}{ Red junglefowl } & Wild-type & $E^{*} N$ & $A$ & - & - & V & - & - & - & - & - & $\mathrm{L}$ & - & - & - & - & ${ }^{2} \mathrm{AY} 220303$ \\
\hline & White Leghorn & $E$ & $A$ & - & - & v & - & K & - & I & - & - & $\mathrm{L}$ & $R$ & - & - & ${ }^{2} \mathrm{AY} 220304$ \\
\hline & $\begin{array}{l}\text { Barred plymouth } \\
\text { rock }\end{array}$ & $E$ & A & - & - & v & $\mathrm{T}$ & K & $\mathrm{T}$ & - & - & - & L & $\mathrm{R}$ & - & - & 3 \\
\hline & Fayoumi & $E^{R-\text { Fayoumi }}$ & $A$ & - & - & v & - & - & - & - & $Q$ & - & $\mathrm{L}$ & - & - & - & 4 \\
\hline & Buttercup & $e^{b c}$ & A & - & - & v & $\mathrm{T}$ & K & - & - & - & - & $\mathrm{L}$ & - & $\mathrm{P}$ & - & ${ }^{2}$ AY220305 \\
\hline & Nagoya Cortin & $e^{y}$ & $A$ & W & G & V & - & - & - & - & - & $A$ & $\mathrm{~L}$ & $\mathrm{R}$ & - & $P$ & 3 \\
\hline
\end{tabular}

${ }^{1}$ Bold letters indicate amino acid site associated with Extended brown.

${ }^{2}$ Sequences reported in Kerje et al. (2003).

${ }^{3}$ Sequences reported in Takeuchi et al. (1996b).

${ }^{4}$ Sequence reported in Takeuchi et al. (1996a).

phenotypes (Extended brown, wild-type and intermediate) were genotyped, and there was perfect and significant association between the number of Lys92 alleles and plumage coloration $(P<0.01$, Fisher's exact test).

The Glu92Lys mutation in MC1R has been previously associated with melanism (an overall increase in eumelanin deposition in hairs or feathers) in mice, chickens and bananaquits. Therefore, it is likely that this is the causative mutation of Extended brown in quails. In vitro studies in mice and chickens have shown that this mutation causes constitutive activation at MC1R (Robbins et al. 1993; Ling et al. 2003). The phenotypic effect of the presence of 92Lys is relatively mild in quail. In mice and bananaquits, the presence of a single 92Lys allele leads to eumelanin deposition throughout most hairs or feathers respectively. The situation in chickens is more complex and suggests intragenic epistatic effects on the Glu92Lys mutation. Although most MC1R alleles causing increased melanin deposition encode for 92Lys, they usually also contain at least one other substitution such as $71 \mathrm{Thr}$ or 126Ile (see Table 1; Takeuchi et al. 1996a,b; Kerje et al. 2003; M. Tixier-Boichard, pers. comm.). In addition, the phenotypic effect of Glu92Lys is abrogated by a second substitution in MC1R, His215Pro, as occurs in the buttercup allele (Kerje et al. 2003). In quail, the mild phenotypic effect of 92Lys may be due either to the absence of a positively epistatic mutation at $M C 1 R$, reflecting shared functional similarities of MC1R in galliforms, or to epistasis at another locus.

To determine whether the Glu92Lys mutation in quail and chicken reflected independent events or an ancestral polymorphism, we estimated phylogenies of their MC1R alleles using guineafowl $M C 1 R$ as an outgroup. Phylogenetic reconstructions were performed using neighbourjoining (with HKY85 distances) and maximum likelihood (with an HKY85 model) methods in PAUP* v. 4.0 (Swofford 1998). Results from these methods were consistent in showing that the Glu92Lys substitution occurred independently in the quail and chicken lineages (Fig. 1).

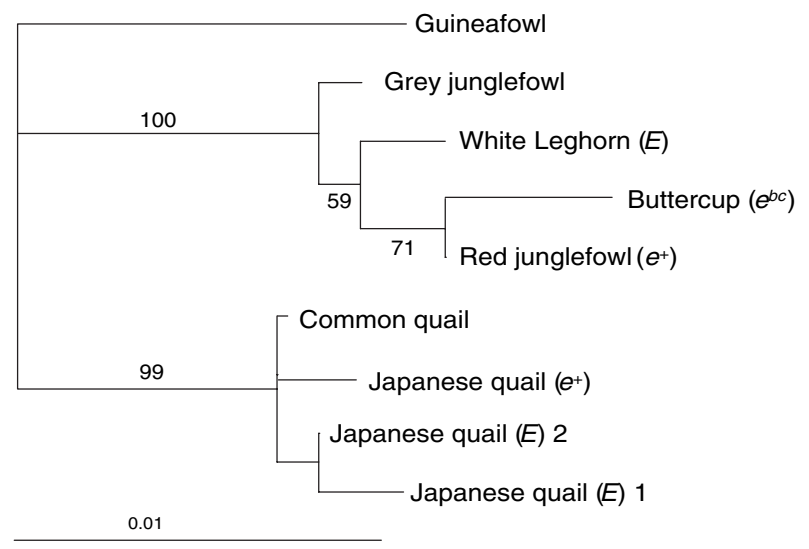

Figure 1 Maximum likelihood of phylogenetic reconstruction of galliform MC1R based on nucleotide sequences. Numbers above branches indicate percent bootstrap support in neighbour-joining analyses with 1000 replicates. The Japanese quail E1 (DQ395089) and E2 (DQ395090) sequences were obtained from French and Japanese flocks respectively. Other species are common quail (Coturnix coturnix; DQ395093), grey junglefowl (Gallus sonneratii; DQ395092) and vulturine guineafowl (Acryllium vulturinum; DQ395094), which was used as an outgroup.

Preliminary data from a survey of the molecular evolution of MC1R across galliforms show that this mutation has in fact occurred independently at least two other times in this group, including in curassows (Crax) and in peacock pheasants (Polyplectron) (N. Nadeau, unpublished results). The presence of four independent occurrences of the Glu92Lys mutation in galliforms, each associated with the same G272A transition, suggests high mutability at this nucleotide site in MC1R.

\section{Acknowledgements}

We thank David Gourichon and Chantal Moussu (INRAUGFA, Nouzilly) for taking care of the experimental quail 
and collecting the samples. Japanese stock with the Extended brown mutation were kindly provided by Professor S. Ito from Gifu University (Japan). We thank Michèle TixierBoichard for comments on the manuscript. This work was supported by the NERC.

\section{References}

Cheng K. \& Kimura M. (1990) Mutations and major variants in Japanese quail. In: Poultry Breeding and Genetics (Ed. by R. Crawford), pp. 333-62. Elsevier, Amsterdam.

Jackson I. (1997) Homologous pigmentation mutations in human, mouse and other model organisms. Human Molecular Genetics $\mathbf{6}$, 1613-24.

Kerje S., Lind J., Schütz K., Jensen P. \& Andersson L. (2003) Melanocortin 1-receptor $(M C 1 R)$ mutations are associated with plumage colour in chicken. Animal Genetics 34, 241-8.

Klungland H., Våge D.I., Gomezraya L., Adalsteinsson S. \& Lien S. (1995) The role of melanocyte-stimulating hormone (MSH) receptor in bovine coat color determination. Mammalian Genome $\mathbf{6}$, 636-9.

Ling M.K., Lagerström M.C., Fredriksson R., Okimoto R., Mundy N.I., Takeuchi S. \& Schiöth H.B. (2003) Association of feather colour with constitutively active melanocortin 1 receptors in chicken. European Journal of Biochemistry 270, 1441-9.

Mundy N.I., Badcock N.S., Hart T., Scribner K., Janssen K. \& Nadeau N.J. (2004) Conserved genetic basis of a quantitative plumage trait involved in mate choice. Science 303, 18701873.

Nachman M.W., Hoekstra H.E. \& D'Agostino S.L. (2003) The genetic basis of adaptive melanism in pocket mice. Proceedings of the National Academy of Sciences of the United States of America 100, 5268-73.

Robbins L.S., Nadeau J.H., Johnson K.R., Kelly M.A., Roselli-Rehfuss L., Baack E., Mountjoy K.G. \& Cone R.D. (1993) Pigmentation phenotypes of variant extension locus alleles result from point mutations that alter MSH receptor function. Cell 72, 827-34.

Swofford, D. (1998) PAUP* 4.0. Phylogenetic Analysis Using Parsimony. Sinauer Associates, Sunderland, Massachusetts. [Note: this is a computer program].

Takeuchi S., Suzuki H., Hirose S., Yabuuchi M., Sato C., Yamamoto H. \& Takahashi S. (1996a) Molecular cloning and sequence analysis of the chick melanocortin-1 receptor gene. Biochimica et Biophysica Acta 1306, 122-6.

Takeuchi S., Suzuki H., Yabuuchi M. \& Takahashi S. (1996b) A possible involvement of melanocortin 1-receptor in regulating feather color pigmentation in the chicken. Biochimica et Biophysica Acta 1308, 164-8.

Theron E., Hawkins K., Bermingham E., Ricklefs R. \& Mundy N.I. (2001) The molecular basis of an avian plumage polymorphism in the wild: a point mutation in the melanocortin-1 receptor is perfectly associated with melanism in the bananaquit (Coereba flaveola). Current Biology 11, 550-7. 